\title{
DISTRIBUTION PATTERNS AND TROPHIC STRUCTURE OF SOFT- BOTTOM POLYCHAETE ASSEMBLAGES IN A NORTH-WESTERN MEDITERRANEAN SHALLOW-WATER BAY
}

\author{
Daniel Martin, Susana Pinedo and Rafael Sardá \\ Centre d'Estudis Avançats de Blanes (CSIC). Camí Sta. Bàrbara s/n. \\ 17300 Blanes, Girona. Spain.
}

Running head: Soft-bottom polychaetes of a shallow-water bay

\begin{abstract}
This study describes the spatial distribution and trophic structure of the polychaetes inhabiting the soft-bottoms of Alfacs Bay, a semi-enclosed, shallow-water area (Ebro Delta, north-western Mediterranean). The hydrographic regime is basically marine, with a combination of seawater renewal and continental runoff causing permanent stratification. The Bay was affected by anthropogenic activities (viz. influx of irrigation waters, largescale aquaculture, and periodical dredging at the mouth). 41 samples were taken during summer (July 1987 and September 1992). 101 polychaete species were identified, with an average density and biomass of 6370(65023700) ind $\cdot \mathrm{m}^{-2}$ and 7.52(0.87-66) DW $\mathrm{g} \cdot \mathrm{m}^{-2}$, respectively. Nine assemblages were identified: shelf (stressed, confined, typical), boundary, deep central basin (inner, typical, seaward) and marine (typical, navigation channel). The trophic structure was dominated by deposit-feeding polychaetes (mainly Pseudomastus deltaicus, Heteromastus filiformis, Notomastus latericeus, Mastobranchus trinchesii, Euclymene oerstedii, Clymenura clypeata, Streblospio shrubsolii, Monticellina heterochaeta and Ampharete acutifrons). An increase in the ecological weight of carnivorous polychaetes (mostly Lumbrineris latreilli) from the shelf towards the marine assemblages was also noticed. The analysis of the polychaete taxocoenosis provides key items to understand the functioning of the semi-enclosed, shallow-water system under study.
\end{abstract}

Keywords: Distribution Patterns, Trophic Structure, Infaunal Polychaetes, Semi-enclosed Shallow-Water Bay, North-Western Mediterranean. 


\section{INTRODUCTION}

Besides classical studies of environmental factors, a viable approach to the analysis of a given ecosystem is to define the structural properties of the faunal assemblages that respond differentially to the environmental constraints (Warwick 1986). There appears to be a certain uniformity in the faunal composition of the littoral environments that are partially isolated from coastal waters, which are known as "paralic" environments in the Mediterranean. The main variable generating organization in paralic ecosystems was described as the time of renewal of marine elements at any given point of the system, and was referred to as "confinement" (i.e. with relation to the sea) (Guelorget \& Perthuisot 1992). However, since it is difficult to measure this intuitive concept, the proposed definition was based on benthic zonation patterns, which appeared to be uniform within the paralic domain (Frisoni et al. 1984; Guelorget \& Perthuisot 1992). It is generally accepted that the distribution of benthic species reflects environmental gradients, especially those directly related with the sediment such as grain size, pollution or organic matter gradients (Gray 1974; Pearson \& Rosenberg 1978). Paralic environments are no exception, and thus both the taxonomic composition and the distribution patterns of their fauna are often highly characteristic and specific of each site (Gravina et al. 1989; Palacín et al. 1991; Guelorget \& Perthuisot 1992).

The Ebro Delta includes some of the largest paralic systems in the north-western Mediterranean. Particularly, two large semi-enclosed, shallow-water bays are located on its northern (Fangar Bay) and southern (Alfacs Bay) shorelines. Although most of their shorelines are protected areas, the Ebro Delta supports periodical anthropogenic perturbations, extensive aquaculture of euryhaline fish and shellfish industries. In Alfacs Bay, the input of the rice-field irrigation waters along its northern shoreline and the dredging of a navigation channel towards a cement loading point at its opening also disturb its benthic zonation pattern.

Alfacs Bay is the focus of increasing attention and research. Numerous studies on the functioning of this environment have been carried out: geological origin (Maldonado 1977), hydrography (Camp \& Delgado 1987; Delgado \& Camp 1987), phytoplankton (Delgado 1987), production modelling (Camp et al. 1985, 1991), sediment-water nutrient fluxes (Vidal et al. 1989), benthic bacterial balance (Mallo 1989; Mallo et al. 1993), ecology and systematics of microphytobenthos (Delgado 1989), ecology of macrophytobenthos (Pérez \& Camp 1986; Pérez 1989; Duarte \& Sand-Jensen 1990), spatial distribution and seasonality of meio- and macroinfauna (Palacín 1990; Palacín et al. 1991, 1992, 1993; Sardá et al. 1995).

Polychaete species were particularly abundant in Alfacs Bay, ranging from $32 \%$ to $90 \%$ (in density) and from $40 \%$ to $93 \%$ (in biomass) of the total benthic macroinfauna (Palacín et al. 
1991). However, studies on this group are only partial: taxonomic descriptions (CapaccioniAzzati \& San Martín 1989-90; Martin 1989; Martin \& Giangrande 1991; Capaccioni-Azzati \& Martin 1992), faunal and coenotic analysis of the deepest areas of the Bay (CapaccioniAzzati et al. 1991), short-scale spatial distribution patterns and minimal-area estimates (Martin et al. 1993) and population dynamics and secondary production of some key species (Sardá \& Martin 1993; Martin \& Grémare 1996). Here we analyze the structure and composition of soft-bottom polychaete assemblages in Alfacs Bay to provide a complete mapping based on various biological descriptors. A special effort has been made to describe the spatial distribution of polychaete assemblages and their relationships with environmental variables.

In addition, soft-bottom infaunal distribution depends on trophic strategies and sediment characteristics such as particle size and organic matter content (Sanders 1958; Bloom et al. 1972; Gray 1974; Whitlatch 1981; Snelgrove \& Butman 1994; Pinedo et al. 1997). Thus, we also used feeding guilds and a trophic index (Paiva 1993; Pinedo et al. 1997) to describe the functional structure of the polychaete assemblages of Alfacs Bay and to analyze their relationships with the environmental variables.

We thank Dr. C. Palacín for sharing fieldwork and scientific discussions on the functioning of the Bay and D. J.M. Gili for his scientific support at the beginning of the study. This research was supported by the project CICYT AC 16/84 and by a contract with the former "Direcció General de Ports de Catalunya".

\section{MATERIAL AND METHODS}

Alfacs Bay is a semi-enclosed, shallow-water area located at the southern shore of the Ebro Delta, north-western Mediterranean, $40^{\circ} 33^{\prime}-40^{\circ} 38^{\prime} \mathrm{N} ; 0^{\circ} 32^{\prime}-0^{\circ} 44^{\prime} \mathrm{E}$ (Fig. 1). The Bay measures about $50 \mathrm{Km}^{2}$ and contains about $200 \cdot 10^{6} \mathrm{~m}^{3}$ of seawater. It is isolated and protected from the open sea by a narrow sand bar, with only a $3 \mathrm{Km}$ wide mouth opening to the sea. The average depth is $4 \mathrm{~m}$, with a large shelf following the inner coastal profile (extending from about 0 to $2 \mathrm{~m}$ deep), a deep central area (3 to $6 \mathrm{~m}$ deep) and a narrow connecting slope (from 2 to $3 \mathrm{~m}$ deep). Just at the opening of the Bay, depth increases slowly to $10 \mathrm{~m}$, with maximum values of 11 to $12.5 \mathrm{~m}$ along the navigation channel located off the cement loading point of Alcanar (stations 34 to 39), which is maintained by dredging.

Fresh water runs into the Bay through a complex network of channels, mainly across rice fields, which open along the northern coast (Fig. 1). From this shoreline, this less saline water flows towards the mouth. About $7 \cdot 10^{4}-1.7 \cdot 10^{6} \mathrm{~m}^{3}$ day $^{-1}$ of fresh water is transported from April to October. However, this volume is always less than $1 \%$ of the total capacity of the Bay. Mediterranean seawater reaches Alfacs Bay from west (opening of the Bay) to east (inner corner of the Bay). Thus, stratification permanently characterizes the hydrographic 
conditions of the Bay (Camp \& Delgado 1987). Especially during summer, a more saline and dense marine water layer (i.e. 35 to $36 \%$ ) advances into the Bay, sliding near the bottom beneath the less saline upper water layer (i.e. 20 to 35\%o). Owing to this dominant hydrographic regime of the Bay, the deeper zones of the Bay show a constantly marine salinity. Along the shallow south-eastern shoreline, salinity reaches 37 to $38 \%$ due to evaporation. During summer, the Bay shows a characteristic Redox pattern at the surface of the sediment. Redox values range from -30 to $-170 \mathrm{mV}$ in most of the Bay, reaching positive potentials (up to $20 \mathrm{mV}$ ) along the south-eastern shelf. The most negative Redox potential (down to $-350 \mathrm{mV}$ ) occurs in the northern shelf, around the openings of the outlet channels (Mallo 1989; Mallo et al. 1993).

Another characteristic aspect of the Bay is the large area covered by macrophytes, the most significant autotrophic components of the Bay (Pérez \& Camp 1986; Pérez 1989; Duarte \& Sand-Jensen 1990). The most abundant species are the seagrasses Ruppia cirrhosa and Cymodocea nodosa and the alga Caulerpa prolifera. $R$. cirrhosa occurs in dense beds along the northern shelf, which are replaced by $C$. nodosa in deeper ( 3 to $4 \mathrm{~m}$ ) or less stressed areas. C. nodosa, the most abundant seagrass in the Bay, forms a continuous narrow belt along the northern shore line (mean biomass from 32 to $267 \mathrm{DW} \mathrm{g} \cdot \mathrm{m}^{-2}$ ) and occurs in discontinuous patches along the southern shelf (mean biomass from 60 to $118 \mathrm{DW} \mathrm{g} \cdot \mathrm{m}^{-2}$ ) (Pérez 1989). The alga $C$. prolifera (often mixed with Halopitys incurvus) occurs at the central basin, from the middle towards the opening of the Bay, reaching biomasses of about $50 \mathrm{DW} \mathrm{g} \cdot \mathrm{m}^{-2}$ (authors, personal observations).

A total of 41 samples were collected during two field surveys (Fig. 1). The stations were selected to describe the spatial distribution and trophic structure of the polychaete populations inhabiting the Bay. All samples were obtained during summer using an inflatable boat. Station positions were fixed by "LORAN", and supplemented by relative bearing. The inner part of the Bay (i.e. stations 1 to 23) was sampled in July 1987 by hand or Scuba diving using a plastic corer $\left(200 \mathrm{~cm}^{2}, 20 \mathrm{~cm}\right.$ in depth). The outer part of the Bay (i.e. stations 24 to 41) was sampled in September 1992 using a van Veen grab $\left(600 \mathrm{~cm}^{2}, 20 \mathrm{~cm}\right.$ in depth). Between 1987 and 1992, the structure of the populations was not modified by environmental events other than the recurrent processes described above. The samples were not replicated, as a sampling size of $200 \mathrm{~cm}^{2}$ was previously estimated to be representative of density and diversity studies in the area (Martin et al. 1993). To avoid size-dependent bias, the species richness of the inner assemblages of the Bay was estimated by grouping three samples at random, which gave the same surface area as the grab samples from the outer Bay (i.e. $600 \mathrm{~cm}^{2}$ ). Thus, results were not subjected to statistical analysis, and the trends in species richness were simply described in the corresponding section. Samples were sieved through a $0.5 \mathrm{~mm}$ screen and preserved in a $10 \%$ formalin seawater solution. Parallel core samples or small sub-samples from the grab were collected for organic-content and mechanical granulometric analyses. 
The polychaetes retained by the sieve were classified to the species level and counted. Biomass was determined as dry weight (DW, $24 \mathrm{~h}$ at $70^{\circ} \mathrm{C}$ ). Diversity was estimated using the Shannon index (Shannon 1948) based on both polychaete density and biomass. The species frequency $(\mathrm{F})$, either in the whole Bay or in a given assemblage, was estimated as:

$$
\mathrm{F}=(\mathrm{m} / \mathrm{M}) \cdot 100
$$

where:

$\mathrm{m}=$ number of samples in which a species is present.

$\mathrm{M}=$ total number of samples.

Polychaetes were classified into five trophic groups: F, filter feeders; M, mixed (filter and surface-deposit feeders); S, surface-deposit feeders; SS, subsurface-deposit feeders; C, carnivores, herbivores and omnivores (adapted from (Fauchald \& Jumars 1979; Dauvin \& Ibanez 1986)). Each species was classified into a single trophic group (table 1). The ecological importance of each trophic group at each polychaete assemblage was evaluated using the Trophic Importance Index (Ti) adapted from Paiva (1993) and Pinedo et al. (1997):

$$
\mathrm{Ti}=\underset{\mathrm{i}=1}{\sum} \ln \mathrm{ni}
$$

$\mathrm{s}=$ number of species of the trophic group in the assemblage.

$\ln \mathrm{ni}=$ natural logarithm of the (\% biomass $)+1$ of the $\mathrm{i}^{\text {th }}$ species in the assemblage.

Organic content of dry sediment was estimated as the loss of weight after ashing $\left(60^{\circ} \mathrm{C}\right.$ for $24 \mathrm{~h}$, then $500^{\circ} \mathrm{C}$ for $3 \mathrm{~h}$ ) (Greiser \& Faubel 1988). Sediment was subjected to the standard dry-sieving procedure (Wentworth 1972) for granulometric analysis. The percentage of siltclay $(<63 \mu \mathrm{m})$ was used as a variable.

Contour maps for all abiotic and biotic variables were based on a bidimensional interpolation (40 rows per 63 columns grid size) using Kriging as gridding method. Land nodes were blanked using digitized series of co-ordinates representing the shoreline profile. Polychaete assemblages were defined on the basis of cluster analysis using Czekanovski metrics and the UPGMA aggregation algorithm. The cluster analyses were performed on both percent-transformed density and biomass of species-per-sample matrix. However, although the sorting and weight of samples and species within each cluster slightly varied, both analyses give rise to identical sample clusters. Thus, only that based on biomass was represented. Each sample cluster corresponded to a polychaete assemblage present in Alfacs Bay, while the species clusters defined the most characteristic species of each assemblage or 
group of assemblages. The relationships between sample and species clusters were analyzed using a tabular version of the two-way coincidence test developed by Kikkawa (1968).

One-way analysis of variance (ANOVA) was used to test the differences in the environmental and biological variables between assemblages. Two-way ANOVAs were used to assess the effect of trophic group and polychaete assemblage on each biological variable. Multiple comparisons test was carried out by Tukey Honest Significant Difference test (Tukey HSD) (Zar 1984). Pearson correlation analysis was used to assess the relationships between environmental variables (depth, $\%$ of fine sediments, organic matter content) and the biological descriptors. The assumptions of normality and homoscedasticity, required for parametric analysis (Zar 1984), (as tested by Kolmogorov-Smirnov and Bartlett test, respectively) were met by either raw (diversity), log-transformed (density, species richness) or rank-transformed (depth, \% of fine sediments, organic matter content, biomass, mean individual biomass) data.

\section{RESULTS}

\section{Environmental variables}

The distribution of both silt-clay (Pearson analysis, $\mathrm{r}=0.5, \mathrm{p}<0.002$ ) and organic matter content in the sediment (Pearson analysis, $r=0.6, p<0.0002$ ) was positively correlated with the bathymetry of the Bay (Fig. 2A, 2B). Minimum values (i.e., $<0.06 \%$ for fine sediments and $<0.6 \%$ for the organic matter) occurred in the south-eastern shelf. Maximum values occurred at the maximum depths (i.e. the middle of the Bay and the navigation channel) both for fine sediments $(>90 \%)$ and organic matter (> 5.5\%). There were only two relevant differences in their respective distribution patterns. The highest percentage of fine sediments was homogeneously distributed throughout the deeper bottoms of the Bay. The organic matter content was higher at the inner deep bottoms, but also in the navigation channel. These zones were separated by an area of organically poor sediments just at the opening of the Bay. A high organic content was also observed at the central north shelf facing the outlet channels.

\section{Characteristics of the polychaete taxocoenosis}

A total of 101 species of polychaetes were found in the Bay (table 1), the most frequent being Heteromastus filiformis (66\%), Pseudomastus deltaicus (61\%), Glycera unicornis (59\%), Lumbrineris latreilli (59\%), Euclymene oerstedii (56\%), and Monticellina heterochaeta $(56 \%)$.

The average density was 6370 ind. $\mathrm{m}^{-2}$. The northern shelf harboured both the maximum 
(23700 ind $\cdot \mathrm{m}^{-2}$, north-eastern edge) and minimum (650 ind $\cdot \mathrm{m}^{-2}$, north central zone) densities (Fig. 3B). The remaining of the Bay had intermediate values, the density increasing slightly around the opening of the Bay. The dominant species in density were Pseudomastus deltaicus (21\%), Streblospio shrubsolii (17\%), Heteromastus filiformis (6\%) and Ampharete acutifrons $(5 \%)$.

The average biomass was $7.52 \mathrm{DW} \mathrm{g} \cdot \mathrm{m}^{-2}$, accounting for a mean individual size of $2 \mathrm{DW}$ mg.ind..$^{-1}$. The spatial pattern of biomass showed a clear north-south gradient, with maximum $\left(66 \mathrm{DW} \mathrm{g} \cdot \mathrm{m}^{2}\right)$ and minimum $\left(0.87 \mathrm{DW} \mathrm{g} \cdot \mathrm{m}^{-2}\right)$ values occurring in the southern and north central shelf, respectively (Fig. 3C). The largest individuals (22 DW mg.ind..$^{-1}$ ) occurred at the southern shelf and the smallest $\left(0.1 \mathrm{DW} \mathrm{mg} \cdot \mathrm{ind}^{-1}\right)$ at the north central shelf (Fig. 3D). The main dominant species in biomass were Clymenura clypeata (32\%), Pseudomastus deltaicus (13\%), Notomastus latericeus (6\%) and Mastobranchus trinchesi (5\%).

The average Shannon diversity (based on density data) was 2.69 bite.ind.- ${ }^{-1}$. Maximum (3.89 bite.ind. $\left.{ }^{-1}\right)$ and minimum $\left(0.25\right.$ bite $\cdot$ ind $\left.^{-1}\right)$ values occurred in the slope and the north shelf, respectively (Fig. 3E). The central zone of the Bay showed intermediate values, while diversity was high at the southern shelf and the navigation channel. Using biomass, the maximum (3.90 bite.ind. $\left.{ }^{-1}\right)$ and minimum (0.34 bite.ind. $\left.{ }^{-1}\right)$ diversity values occurred at the navigation channel and the southern shelf, respectively (Fig. 3F), while the average was 2.29 bite-ind..$^{-1}$. Diversity patterns based on density and biomass coincided in showing minimal values at the northern shelf and maximal values at the opening of the Bay and the navigation channel. However, biomass and density diversity patterns differed in that the former had always low diversity values at the shallowest bottoms of the Bay (i.e. both at the north and south shelf), this giving rise to a significant positive correlation between depth and biomass diversity (Pearson analysis, $r=0.7, \mathrm{p}<0.00002$ ).

All trophic groups showed different patterns of distribution in the Bay (Fig. 4). The presence of group $\mathrm{C}$ was maximal following the northeast-southwest axis of the Bay, mainly at the deepest bottoms. Group F occurred just before the opening of the Bay. Group M was present along the northern shelf and in the navigation channel. Group S was present at the northern shelf, with some large individuals occurring at the middle of the Bay and the slope. Group SS showed the highest biomass along the southern shelf of the Bay. Positive correlations were only found between groups $\mathrm{C}$ and $\mathrm{M}$ and depth (Pearson analysis, $\mathrm{r}=0.4, \mathrm{p}$ $<0.006, \mathrm{r}=0.5, \mathrm{p}<0.0009)$, while group SS was negatively correlated with the organic matter content (Pearson analysis, $\mathrm{r}=-0.3, \mathrm{p}<0.04$ ).

\section{Polychaete assemblages}

From the results of the cluster analysis (cofenetic correlation of 0.9 ), 9 clusters of samples and 13 of species were identified (Fig. 5A, table 1). The resulting polychaete assemblages (i.e. 
sample clusters) were named as follows: typical (STY), confined (SCO) and stressed (SST) shelf assemblages; boundary assemblage (BOU); inner (CIN), typical (CTY) and seaward (CSW) central basin assemblages; and typical (MTY) and navigation channel (MCH) marine assemblages (Fig. 5B). Although many species were widely distributed throughout the whole Bay, the following relationships between the assemblages described above and the species clusters can be pointed out: group 1 at SST; group 2 at SCO; group 3 at STY; group 4 at BOU; group 5 at CIN; group 6 at CTY; group 7 at CSW; group 8 at MTY; and group 9 at $\mathrm{MCH}$. The remaining four groups included species which were present at more than one assemblage: group 10 at all shelf and boundary assemblages; group 11 mainly at STY and BOU; group 12 at all assemblages except the shelf ones; and group 13 at CTY, CSW, MTY and $\mathrm{MCH}$ (table 1).

All environmental variables analyzed showed significant differences between assemblages (one way- ANOVA, depth: $\mathrm{F}=64.2$ and $\mathrm{p}<0.00001$, percentage of fine sediments: $\mathrm{F}=8.3$ and $\mathrm{p}<0.00002$, organic matter content: $\mathrm{F}=4.1$ and $\mathrm{p}<0.002$ ) (Fig. 6). All assemblages differed significantly from each other in depth (Tukey HSD, $p<0.001$ ) except for BOU vs. CIN, SST and SCO, CIN vs. CTY, CSW vs. the marine assemblages, and MTY vs. MCH. Conversely, Tukey HSD showed that the significant differences in percentage of fine sediments were due to the low values at the three shelf assemblages (SCO: $p<0.004$, SST: $p$ $<0.02$, STY: $\mathrm{p}<0.0002)$, while those in organic matter content were only caused by the extremely low values at STY $(\mathrm{p}<0.001)$.

All biological descriptors of the polychaete assemblages showed significant differences between assemblages, except the biomass (one-way ANOVA, density: $F=7.27$ and $p<$ 0.0001, density diversity: $\mathrm{F}=7.44$ and $\mathrm{p}<0.0001$, biomass diversity: $\mathrm{F}=4.65$ and $\mathrm{p}<0.001$, mean individual biomass: $\mathrm{F}=2.38$ and $\mathrm{p}<0.04$ ) (Fig. 7). Although some significant differences were caused by MCH (Tukey HSD, vs. CIN: p < 0.04, vs. CTY: p < 0.02), the main responsible were the shelf assemblages (Table 2).

One or two trophic groups dominated the biomass distribution at each polychaete assemblage, except at the SST (Fig. 8A). There was a significant combined effect of both assemblages and trophic groups in biomass distribution (Two-way ANOVA, F = 1.93 and $\mathrm{p}<$ 0.005). The only significant difference occurred between the assemblages SST and MCH (Tukey HSD, $\mathrm{p}<0.04$ ). The biomass distribution of each trophic group among the assemblages was significantly different from one to another $(p<0.0002)$, except for groups $M$ vs. $\mathrm{F}$ and $\mathrm{C}$ vs. S.

The values of the ecological importance index of each trophic group showed the predominance of two or three groups at each assemblage except for the SST (Fig. 8B). As a general trend, deposit-feeding polychaetes dominated all the assemblages of the Bay and carnivorous polychaetes increased their ecological relevance from the shelf towards the marine assemblages. The only significant positive correlation between the trophic importance 
index and the environmental parameters at each assemblage occurred between group $\mathrm{C}$ and depth (Pearson analysis, $\mathrm{r}=0.9, \mathrm{p}<0.002$ ).

\section{DISCUSSION}

Littoral environments that are partially isolated from coastal waters (such as deltas, estuaries, coastal lagoons, semi-enclosed bays or fjords) might be considered as simple boundaries between marine and continental ecosystems. However, growing evidence suggests that they have specific dynamics, clearly differing from those of the two ecosystems within which they are located. In fact, these environments, i.e. the paralic systems of Guelorget and Perthuisot (1992), seem to be characterized by gradients, irrespective of the type of variable analyzed (viz. hydrological, sedimentological). However, benthic zonation often appears to be independent of the environmental gradients defined on the basis of a single descriptor such as salinity or, more recently, confinement. In some cases, the most relevant environmental variables are more highly correlated to each other than to the variables describing the benthic zonation so that it becomes very difficult (if not impossible) to sort out a principal factor (Lardicci et al. 1993).

The lack of consistency in mono-factorial approaches to explain distribution patterns clearly emerged from the analysis of the polychaete taxocoenosis of Alfacs Bay. Only the Shannon diversity based in biomass and depth showed a significant relationship. Sediment characteristics were homogeneous along the central axis of the Bay, while polychaete diversity increased seaward. Thus, it could be tentatively assumed that the polychaete assemblages seemed to follow the typical organization expected for a confinement-controlled system. However, this interpretation ignores two main points. First, the highest increase in biomass diversity along this axis occurred owing to the channel assemblage (which is a modified facies of the typical marine assemblage). Second, the main changes in density, biomass and, excluding the navigation channel, in diversity, occurred in the shelf of the Bay. For example, stations 9 and 13 , which are more or less at the same distance from the sea, were very different (i.e. 650 ind. $\mathrm{m}^{-2}, 1 \mathrm{DW} \mathrm{g} \cdot \mathrm{m}^{-2}$ and 3 species and 3400 ind. $\mathrm{m}^{-2}, 66 \mathrm{DW} \mathrm{g} \cdot \mathrm{m}^{-2}$ and 16 species, respectively). Conversely, stations 2 (inside the Bay) and 16 (close to the opening) were similar (i.e. 3600 ind $\cdot \mathrm{m}^{-2}, 14 \mathrm{DW} \mathrm{g} \cdot \mathrm{m}^{-2}$ and 16 species and $4250 \mathrm{ind} \cdot \mathrm{m}^{-2}, 9 \mathrm{DW} \mathrm{g} \cdot \mathrm{m}^{-2}$ and 16 species, respectively). On the other hand, a typical succession such as that proposed by Pearson and Rosenberg (1978) for an organic enrichment gradient occurred in the north shelf from the centre to both the east (towards the inner corner of the Bay) and the west (towards the open sea). Thus, in these assemblages, the organization of polychaetes may not be simply explained by confinement.

Previous studies on the functioning of Alfacs Bay identified some of the main sources of variability, which may influence the structure and distribution of benthic fauna. Macrofaunal 
assemblages were affected by the presence of macrophytes that favoured the stability of sediments and were a source of oxygen, energy and food (i.e. directly through herbivorism or indirectly as a source of detritic material) (Pérez \& Camp 1986; Martin 1992). The seasonal freshwater inflow carrying terrigenous materials into the Bay (rather than the hydrodynamic regime) seemed to regulate the distribution of the bottom surface sediment and, thus, the distribution of meio- and macrofaunal assemblages that showed a north (origin of the input) to south (lacking the input) orientation (Palacín et al. 1991). Owing to the permanent stratification of the water column in the Bay (Camp \& Delgado 1987), the low salinities that are expected to be associated with the freshwater inflow have no direct influence on the bottom fauna, except in the immediate vicinity of the outlet channels (Palacín et al. 1991). The distance to the point of communication with the sea (often considered as a synonymy of confinement) was suggested as the main factor affecting the polychaetes inhabiting the deepest bottoms of the Bay, whose assemblages seemed to show a south-west (Bay opening) to north-east orientation (Capaccioni-Azzati et al. 1991). However, our approach points out that the distribution pattern of polychaetes in Alfacs Bay can only be explained by a combination of all the above mentioned factors, together with others such as the man-induced disturbance caused by the periodical dredging of the navigation channel at the opening of the Bay.

From a hydrographic point of view, the whole Alfacs Bay is basically marine. However, the northern shelf of the Bay was strongly influenced by the terrestrial inputs, this giving rise to a polychaete assemblage (i.e. SST) that showed the lowest values for all biological descriptors. The unpredictable and aperiodic mixing of continental and marine water masses gives rise to the other assemblage at the northern shelf (i.e. SCO) that may be considered a physically-controlled assemblage (sensu Sanders 1969). As often reported for other areas (viz. Sanders 1958; Pearson \& Rosenberg 1978; Nicolaidou \& Papadopoulou 1989), opportunistic species (mainly surface deposit feeders, such as Streblospio shrubsolii, and subsurface deposit feeders, such as Capitella cf capitata) are dominant, showing high densities, small sizes, and low species richness (Martin \& Grémare 1996; Sardá \& Martin 1993). In contrast, the southern shelf was favoured by the productivity generated in the whole Bay by the continental runoff. The inputs themselves hardly reached the area while the salinity was buffered by the evaporation (Camp \& Delgado 1987). Their bottoms have deep oxygenated sandy sediments (Mallo et al. 1993) and the seagrass beds exert a beneficial influence (e.g. food source, sediment stabilization, retention of particulate matter from the water column) (Pérez \& Camp 1986; Pérez 1989; Duarte \& Sand-Jensen 1990). These result locally in a high environmental stability and a high diversity of microhabitats giving rise to a structurally and functionally complex assemblage (i.e. STY) that may be considered biologically accommodated (sensu Sanders 1969). Marine waters always occupied the deeper central basin (Camp \& Delgado 1987) which, in turn, was also affected by the deposition of materials carried into the Bay by the continental runoff. The gradual but ongoing sedimentation originated in the northern 
shoreline allows these bottoms to be populated by biologically accommodated assemblages, which were adapted to the high organic matter and silt-clay content. Besides a hypothetical difference in confinement, the environmental conditions throughout the central basin are homogeneous. We suggest that the difference between the two main polychaete assemblages present in the central basin (i.e. CIN and CTY) may be caused by the presence of Caulerpa prolifera in the latter. The third assemblage (i.e. CSW) was considered a transition to the marine assemblage (i.e. MTY). Finally, the sudden increase in depth maintained by periodical dredging forced the navigation channel to act as a decantation basin (sensu Salen-Picard 1985), where silt-clay sediments accumulate. The polychaete assemblage there differs from that of the surrounding bottoms in the presence of species (see group 9 in Table 1) which are commonly found at greater depths in coastal areas.

The combination of concurrent processes (protection by sand bar, seawater renewal, continental run off, sedimentation, evaporation, presence of macrophytes, dredging) in Alfacs Bay gives rise to a highly productive system (Camp et al. 1991; Palacín et al. 1991). This system supports a high biomass of polychaetes, mainly represented by deposit feeders, whose populations reached high secondary production rates (about $16 \mathrm{DW} \mathrm{g} \cdot \mathrm{m}^{-2} \cdot \mathrm{y}^{-1}$ for Streblospio shrubsolii and up to $37 \mathrm{DW} \mathrm{g} \cdot \mathrm{m}^{-2} \cdot \mathrm{y}^{-1}$ for Capitella cf capitata) (Sardá \& Martin 1993; Martin \& Grémare 1996). It has been hypothesized that deltas, estuaries and lagoons are often stressed by the large variations of environmental factors so that there is a decline in species number (Barnes 1974) and the resulting benthic zonation is often simple (López-Jamar 1981; Frisoni et al. 1984; Carrada et al. 1987; Morri et al. 1988; Nicolaidou et al. 1988; Elliott \& Taylor 1989; Quintino et al. 1989). In Alfacs Bay, however, the environmental variability results in a high level of spatial heterogeneity that is reflected in the presence, on a very small spatial scale, of 101 polychaete species defining 9 clearly different assemblages. We suggest that both the use of appropriately designed sampling strategies and a species level taxonomic approach may reveal complex faunal distribution patterns.

We feel that the absence of significant correlations between most environmental variables and the biological descriptors of the polychaete taxocoenosis reveals more about the functioning of the system than the few found. Thus, we conclude that the distribution pattern and trophic-functional organization of polychaetes in Alfacs Bay resulted from a complex network of interactions between different environmental factors. However, as often occurs in coastal lagoons (Bianchi \& Morri 1985; Gravina et al. 1988; Lardicci et al. 1993) and in the open sea (Pocklington \& Wells 1992), the analysis of the polychaete taxocoenosis provides key items to understand the functioning of the system under study.

\section{REFERENCES}

Barnes, R.S.K., 1974. Estuarine biology.- Edward Arnold Ltd., London. 77 pp. 
Bianchi, C.N. \& C. Morri, 1985. I policheti come descrittori della struttura trofica degli ecosistemi marini.Oebalia 11: 203-214.

Bloom, S.A., J.L. Simon \& V.D. Hunter, 1972. Animal-sediment relations and community analysis of a Florida estuary.- Marine Biology 15: 43-56.

Camp, J. \& M. Delgado, 1987. Hidrografía de las bahías del Delta del Ebro.- Investigación Pesquera. Barcelona 51: $351-369$.

Camp, J., O. Delgado, M. Delgado, M. Pérez \& M. Vidal, 1985. Algunes idees sobre el model de producció a les badies del Delta de l' Ebre.- Treballs de la Societat Catalana de Biologia 37: 65-68.

Camp, J., J. Romero, M. Pérez, M. Vidal, M. Delgado \& A. Martínez, 1991. Production-consumption budget in an estuarine bay: How anoxia is prevented in a forced system.- Oecologia Aquatica 10: 145-152.

Capaccioni-Azzati, R. \& D. Martin, 1992. Pseudomastus deltaicus gen. et. sp. n. (Polychaeta, Capitellidae) from a shallow water bay in the northwestern Mediterranean sea.- Zoologica Scripta 21: 247-250.

Capaccioni-Azzati, R. \& G. San Martín, 1989-90. Pionosyllis anophthalma n. sp., a new Syllidae (Polychaeta) from the Spanish Mediterranean coasts.- Oebalia 16: 41-48.

Capaccioni-Azzati, R., S. Villora-Moreno, A.M. García-Carrascosa \& F.J. Torres-Gávila, 1991. Distributional patterns of Polychaeta in the Alfaques Inlet (Ebro river Delta; western Mediterranean): faunistic and coenotic analysis of an estuarine system.- Bulletin of Marine Science 48: 369-375.

Carrada, G.C., V.U. Ceccherelli \& I. Ferrari, 1987. Les lagunes Italiennes.- Bulletin d'Ecologie 18: 149-158.

Dauvin, J.C. \& F. Ibanez, 1986. Variations à long-terme (1977-1985) du peuplement des sables fins de la Pierre Noire (Baie de Morlaix, Manche Occidentale): analyse statistique de l'évolution structurale.- Hydrobiologia 142: $171-186$.

Delgado, M., 1987. Fitoplancton de las bahías del Delta del Ebro.- Investigación Pesquera. Barcelona 51: 517548.

Delgado, M., 1989. Abundance and distribution of microphytobenthos in the Bays of Ebro Delta (Spain).Estuarine, Coastal and Shelf Science 29: 183-194.

Delgado, M. \& J. Camp, 1987. Abundancia y distribución de nutrientes inorgánicos disueltos en las bahías del delta del Ebro.- Investigación Pesquera. Barcelona 51: 427-441.

Duarte, C.M. \& K. Sand-Jensen, 1990. Seagrass colonization: patch function and patch growth in Cymodocea nodosa.- Marine Ecology Progress Series 65: 193-200.

Elliott, M. \& J.C. Taylor, 1989. The production ecology of the subtidal benthos of the Forth Estuary, Scotland.Scientia Marina 53: 531-541.

Fauchald, K. \& P.A. Jumars, 1979. The diet of worms: A study of polychaete feeding guilds.- Oceanography and Marine Biology: An Annual Review 17: 193-284.

Frisoni, G., O. Guelorget \& J.P. Perthuisot, 1984. Diagnose écologique apliquée a la mise en valeur biologique des lagunes côtieres méditerranéenes: Approche méthodologique.- GFCM Studies and Reviews / Études et Revues du CGPM 61: 39-95.

Gravina, M.F., G.D. Ardizzone \& A. Giangrande, 1988. Selecting factors in polychaete communities of Central Mediterranean coastal lagoons.- Internationale Revue der gesammten Hydrobiologie 73: 465-476.

Gravina, M.F., G.D. Ardizzone, F. Scaletta \& C. Chimenz, 1989. Descriptive analysis and classification of benthic communities in some Mediterranean coastal lagoons (Central Italy).- P.S.Z.N. I: Marine Ecology 10: $141-166$.

Gray, J.S., 1974. Animal-sediment relationships.- Oceanography and Marine Biology: An Annual Review 12: 223-261.

Guelorget, O. \& J.P. Perthuisot, 1992. Paralic Ecosystems.- Vie et Milieu 42: 215-251.

Kikkawa, J., 1968. Ecological association of bird species and habitats in Eastern Australia: Similarity analysis.Journal of Animal Ecology 37: 143-165. 
Lardicci, C., M. Abbiati, R. Crema, C. Morri, C.N. Bianchi \& A. Castelli, 1993. The distribution of polychaetes along environmental gradients: An example from the Orbetello Lagoon, Italy.- P.S.Z.N. I: Marine Ecology 14: 35-52.

López-Jamar, E., 1981. Spatial distribution of the infaunal benthic communities of the Ria de Muros, NorthWest of Spain.- Marine Biology 63: 29-37.

Maldonado, A., 1977. Introducción geológica al Delta del Ebro.- Treballs de la Institució Catalana de Història Natural. Barcelona. 8: 7-45.

Mallo, S., 1989. Estudio de la variación espacio-temporal de la desnitrificación bacteriana en sedimentos marinos litorales y su contribución al balance de nitrógeno de los sitemas.- Doctoral Thesis, Universidad de Barcelona. $218 \mathrm{pp}$.

Mallo, S., F. Vallespinós, S. Ferrer \& D. Vaqué, 1993. Microbial activities in estuarine sediments (Ebro Delta, Spain) influenced by organic matter influx.- Scientia Marina 57: 31 .

Martin, D., 1989. Revisión de las especies de Owenidae (Annelida, Polychaeta) de la península Ibérica.- Scientia Marina 53: 47-52.

Martin, D., 1992. Macroinfauna de una bahía Mediterránea. Estudio de los niveles de organización de las poblaciones de Anélidos Poliquetos.- Publicacions de l'Universitat de Barcelona, Barcelona. 456 pp.

Martin, D. \& A. Giangrande, 1991. Novafabricia bilobata sp. nov. (Polychaeta, Sabellidae, Fabriciinae) from the Mediterranean Sea.- Ophelia 33: 113-120.

Martin, D. \& A. Grémare, 1996. Secondary production of Capitella sp. (Polychaeta: Capitellidae) inhabiting different organically enriched environments.- Scientia Marina 61: 99-109.

Martin, D., E. Ballesteros, J.M. Gili \& C. Palacín, 1993. Small-scale structure of infaunal polychaete communities in an estuarine environment: Methodological approach.- Estuarine, Coastal and Shelf Science 36: $47-58$.

Morri, C., M. Abbate, C.N. Bianchi, V. Damiani \& S. Sgorbini, 1988. Résultats préliminaires d'un étude hydrobilogique sur l'estuaire du fleuve Magra (Ligurie, Italia). II - Zonation benthique.- Rapports de la Commission Internationale pour l'Exploration de la Mer Méditerranéene 31: 65.

Nicolaidou, A. \& K.N. Papadopoulou, 1989. Factors affecting the distribution and diversity of polychaetes in Ambrakikos Bay, Greece.- P.S.Z.N. I: Marine Ecology 10: 193-204.

Nicolaidou, A., F. Bourgoutzani, A. Zenetos, O. Guelorget \& J.P. Perthuisot, 1988. Distribution of molluscs and polychaetes in coastal lagoons of Greece.- Estuarine, Coastal and Shelf Science 26: 337-350.

Paiva, P.C., 1993. Trophic structure of a shelf polychaete taxocoenosis in southern Brazil.- Cahiers de Biologie Marine 35: 39-55.

Palacín, C., 1990. Estudio ecológico de la meiofauna bentónica de la bahía de Els Alfacs (Delta del Ebre). Ecología y sistemática de las poblaciones de nematodos.- Doctoral Thesis, Universitat de Barcelona. 406 pp.

Palacín, C., D. Martin \& J.M. Gili, 1991. Features of spatial distribution of benthic infauna in a Mediterranean shallow-water bay.- Marine Biology 110: 315-321.

Palacín, C., J.M. Gili \& D. Martin, 1992. Evidence for coincidence of meiofauna spatial heterogeneity with eutrophication processes in a shallow-water Mediterranean bay.- Estuarine, Coastal and Shelf Science 35: $1-16$.

Palacín, C., J.M. Gili \& D. Martin, 1993. Morphological variation in nematode communities in relation to eutrophication processes in a shallow-water Mediterranean bay.- In: Aldrich, J.C. (ed.) Quantified Phenotypic Responses in Morphology and Physiology, pp. 239-246. JAPAGA, Asford.

Pearson, T.H. \& R. Rosenberg, 1978. Macrobenthic succession in relation to organic enrichment and pollution in marine environment.- Oceanography and Marine Biology: An Annual Review 16: 229-311.

Pérez, M., 1989. Fanerógamas marinas en sistemas estuáricos: Producción, factores limitantes y algunos aspectos del ciclo de nutrientes.- Doctoral Thesis, Universidad de Barcelona. 200 pp. 
Pérez, M. \& J. Camp, 1986. Distribución espacial y biomasa de las praderas de fanerógamas marinas de las bahías del Delta del Ebro.- Investigación Pesquera. Barcelona 50: 519-530.

Pinedo, S., R. Sardá \& D. Martin, 1997. Comparative study of the trophic structure of the soft bottom assemblages in the Bay of Blanes (Western Mediterranean Sea).- Bulletin of Marine Science 60: 529-543.

Pocklington, P. \& P.G. Wells, 1992. Polychaetes. Key taxa for marine environmental quality monitoring.Marine Pollution Bulletin 24: 593-598.

Quintino, V., A.M. Rodrigues \& F. Gentil, 1989. Assessment of macrozoobenthos communities in the lagoon of Obidos, Western Coast of Portugal.- Scientia Marina 53: 645-654.

Salen-Picard, C., 1985. Indicateus biologiques et sedimentation en milieu circalittoral méditerranéen.- Rapports de la Commission Internationale pour l'Exploration de la Mer Méditerranéene 29: 211-212.

Sanders, H.L., 1958. Benthic studies in Buzzards Bay. I. Animal-sediment relationships.- Limnology and Oceanography 3: 245-258.

Sanders, H.L., 1969. Benthic marine diversity and the stability-time hypothesis.- Brookhaven symposia in biology 22: 71-80.

Sardá, R. \& D. Martin, 1993. Populations of Streblospio (Polychaeta, Spionidae) in temperate zones: demography and production.- Journal of the Marine Biological Association of the United Kingdom 73: 769-784.

Sardá, R., D. Martin, S. Pinedo, A. Dueso \& M.J. Cardell, 1995. Seasonal dynamics of shallow-water benthic communities in the Western Mediterranean.- In: Nicolaidou, A. (ed.) The biology and ecology of shallow coastal waters, pp. 191-198. Olssen \& Olssen, Fredensborg.

Shannon, C.E., 1948. A mathematical theory of communication.- Belgium Systems and Technical Furnishing 27: 379-423,623-656.

Snelgrove, P.V.R. \& C.A. Butman, 1994. Animal-Sediment relationships revisited: Cause versus effect.Oceanography and Marine Biology: An Annual Review 32: 111-177.

Vidal, M., J. Romero \& J. Camp, 1989. Sediment-water nutrient fluxes: Preliminary results of in situ measurements in Alfaques Bay, Ebro river Delta.- Scientia Marina 53: 505-511.

Warwick, R.M., 1986. A new method for detecting pollution effects on marine macrobenthic communities.Marine Biology 92: 557-562.

Wentworth, W., 1972. A scale of grade and class terms for clastic sediments.- Journal of Geology 30: 377-392.

Zar, J.H., 1984. Biostatistical Analysis.- Prentice Hall International, New Jersey. 718 pp. 
Table 1. Two-way coincidence analysis showing the relationships between sample and species clusters based on polychaete density in Alfacs Bay. SPC: Species groups identified in the cluster analysis; TROF: Trophic groups (codes as in Fig. 4); DEN: mean polychaete density (ind. $\mathrm{m}^{-2}$ ); BIO: mean polychaete biomass (DW $\mathrm{g} \mathrm{m}^{-2}$ ); the

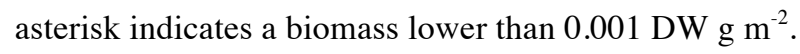

\begin{tabular}{|c|c|c|c|c|c|c|c|c|c|c|c|c|c|c|c|c|c|c|c|c|}
\hline \multirow{3}{*}{ SPC } & \multirow[b]{3}{*}{ SPECIES } & \multirow[b]{3}{*}{ TROF } & \multicolumn{6}{|c|}{ SHELF } & \multirow{2}{*}{\multicolumn{2}{|c|}{ BOUNDARY }} & \multicolumn{6}{|c|}{ CENTRAL } & \multicolumn{4}{|c|}{ MARINE } \\
\hline & & & \multicolumn{2}{|c|}{ STRESSED } & \multicolumn{4}{|c|}{ CONFINED TYPICAL } & & & INN & JER & TYPI & ICAL & SEAV & NARD & TYPI & ICAL & CHAI & NNEL \\
\hline & & & DEN & $\mathrm{BIO}$ & DEN & $\mathrm{BIO}$ & DEN & $\mathrm{BIO}$ & DEN & $\mathrm{BIO}$ & DEN & BIO & DEN & $\mathrm{BIO}$ & EN & $\mathrm{BIO}$ & DEN & $\mathrm{BIO}$ & DEN & $\mathrm{BIO}$ \\
\hline & Scolelepis tridentata (Southern, 1914) & $\mathrm{S}$ & 17 & 0,086 & - & - & - & - & - & - & - & - & - & - & - & - & - & - & - & - \\
\hline & Spirorbis marioni Caullery \& Mesnil, 1897 & $\mathrm{~F}$ & 17 & * & - & - & - & - & - & - & - & - & - & - & - & - & - & - & - & - \\
\hline & Lumbrineris coccinea (Renier, 1804) & $\mathrm{C}$ & 34 & 0,003 & - & - & - & - & - & - & - & - & - & - & - & - & - & - & - & - \\
\hline & Pseudopolydora paucibranchiata (Claparède, 1870) & M & 17 & 0,003 & - & - & - & - & - & - & - & - & - & - & - & - & - & - & - & - \\
\hline 2 & Capitella capitata (Fabricius, 1780) & SS & 84 & 0,022 & 1434 & 0,105 & 65 & 0,003 & 17 & 0,003 & - & - & - & - & - & - & - & - & - & - \\
\hline 2 & Nereis (Hediste) diversicolor (O.F. Müller, 1776) & M & 50 & 0,119 & 67 & 0,158 & - & - & - & - & - & - & - & - & - & - & - & - & - & - \\
\hline & Malacoceros fuliginosus (Claparède, 1870) & $\mathrm{S}$ & - & - & 934 & 0,103 & - & - & - & - & - & - & - & - & - & - & - & - & 37 & 0,070 \\
\hline & Streblospio shrubsolii (Buchanan, 1890) & $\mathrm{S}$ & - & - & 14384 & 2,337 & - & - & - & - & - & - & - & - & - & - & - & - & - & - \\
\hline 3 & Paraonis fulgens (Levinsen, 1883) & $\mathrm{S}$ & - & - & - & - & 693 & 0,072 & - & - & - & - & - & - & 45 & 0,047 & - & - & - & - \\
\hline 3 & Scolaricia typica Eisig, 1914 & $\mathrm{~s}$ & - & - & - & - & 236 & 0,245 & - & - & 34 & 0,015 & - & - & - & - & - & - & - & - \\
\hline & Glycera capitata Orsted, 1843 & $\mathrm{C}$ & - & - & - & - & 8 & 0,003 & - & - & - & - & - & - & - & - & - & - & - & - \\
\hline & Glycera trydactila Schmarda, 1861 & $\mathrm{C}$ & - & - & - & - & 15 & 0,103 & 17 & 0,100 & - & - & - & - & - & - & - & - & - & - \\
\hline & Scolelepis squamata (O.F. Müller, 1876) & $\mathrm{S}$ & - & - & - & - & 22 & 0,025 & - & - & - & - & - & - & - & - & - & - & - & - \\
\hline & Ehlersia ferruginea Langerhans, 1881 & $\mathrm{C}$ & - & - & - & - & 8 & 0,001 & - & - & - & - & - & - & - & - & - & - & - & - \\
\hline 4 & Amphiglena mediterranea (Leydig, 1851) & $\mathrm{F}$ & - & - & - & - & 15 & 0,002 & 84 & 0,004 & - & - & - & - & - & - & - & - & - & - \\
\hline & Parapionosyllis labronica Cognetti, 1965 & $\mathrm{C}$ & - & - & - & - & 15 & 0,001 & 17 & * & - & - & - & - & - & - & - & - & - & - \\
\hline & Amphytrite variabilis (Risso, 1826) & $\mathrm{S}$ & - & - & - & - & - & - & 17 & 0,760 & - & - & - & - & - & - & - & - & - & - \\
\hline & Chaetozone caputesocis (Saint-Joseph, 1894) & $\mathrm{S}$ & - & - & - & - & - & - & 17 & 0,005 & - & - & - & - & - & - & - & - & - & - \\
\hline & Eumida parva Saint-Joseph, 1888 & $\mathrm{C}$ & - & - & - & - & - & - & 17 & 0,003 & - & - & - & - & - & - & - & - & - & - \\
\hline & Sabellaria alcocki Gravier, 1906 & $\mathrm{~F}$ & - & - & - & - & - & - & 17 & 0,053 & - & - & - & - & - & - & - & - & - & - \\
\hline & Caulleriella bioculata (Keferstein, 1862) & $\mathrm{S}$ & - & - & - & - & - & - & 34 & 0,002 & - & - & - & - & - & - & - & - & - & - \\
\hline & Ophiodromus pallidus (Claparède, 1864) & $\mathrm{C}$ & - & - & - & - & - & - & 34 & 0,008 & - & - & 9 & 0,001 & - & - & - & - & - & - \\
\hline & Aphelochaeta marioni (Saint-Joseph, 1894) & $\mathrm{s}$ & - & - & - & - & - & - & 34 & 0,007 & - & - & 14 & 0,005 & 22 & 0,002 & 11 & 0,057 & 88 & 0,020 \\
\hline & Chaetozone setosa Malmgren, 1867 & $\mathrm{~S}$ & - & - & - & - & - & - & 67 & 0,007 & - & - & - & - & - & - & - & - & - & - \\
\hline & Prionospio fallax Södeström, 1920 & $\mathrm{~S}$ & - & - & - & - & 36 & 0,006 & 67 & 0,003 & - & - & 6 & 0,001 & - & - & - & - & - & - \\
\hline & Magelona equilamellae Harmelin, 1964 & $\mathrm{~S}$ & - & - & - & - & 15 & 0,043 & 100 & 0,372 & 17 & 0,010 & 20 & 0,012 & - & - & 56 & 0,106 & 17 & 0,015 \\
\hline & Nematonereis unicornis (Grube, 1840) & $\mathrm{C}$ & - & - & - & - & 8 & 0,007 & 67 & 0,356 & - & - & - & - & - & - & - & - & - & - \\
\hline & Pettiboneia urciensis Campoy \& San Martín, 1980 & $\mathrm{C}$ & - & - & - & - & - & - & 117 & 0,004 & - & - & - & - & - & - & - & - & - & - \\
\hline & $\begin{array}{l}\text { Pionosyllis anophthalma Capaccioni \& San Martín, } \\
1990\end{array}$ & $\mathrm{C}$ & - & - & - & - & - & - & 67 & 0,012 & - & - & - & - & - & - & - & - & - & - \\
\hline & Peresiella clymenoides Harmelin, 1968 & SS & - & - & - & - & - & - & 17 & 0,009 & - & - & - & - & - & - & - & - & - & - \\
\hline 5 & Poecilochaetus serpens Allen,1904 & $\mathrm{S}$ & - & - & - & - & - & - & - & - & 84 & 0,063 & 30 & 0,030 & - & - & - & - & - & - \\
\hline $\mathcal{J}$ & Eunice vittata (Delle Chiaje, 1828) & $\mathrm{C}$ & - & - & - & - & - & - & - & - & 17 & 0,005 & 2 & 0,003 & - & - & - & - & - & - \\
\hline & Lanice conchilega (Pallas, 1766) & $\mathrm{S}$ & - & - & - & - & - & - & - & - & 17 & 1,216 & - & - & - & - & - & - & - & - \\
\hline & Myxicola aesthetica (Claparède, 1870) & $\mathrm{S}$ & - & - & - & - & - & - & - & - & 17 & 4,457 & - & - & - & - & - & - & - & - \\
\hline & Prionospio cf multibranchiata Berkeley, 1927 & $\mathrm{~S}$ & - & - & - & - & - & - & - & - & 17 & 0,002 & - & - & - & - & - & - & - & - \\
\hline 6 & Eteone picta Quatrefages, 1865 & $\mathrm{C}$ & - & - & - & - & - & - & - & - & - & - & 9 & 0,002 & - & - & - & - & - & - \\
\hline O & Potamilla torelli Malmgren, 1865 & $\mathrm{~F}$ & - & - & - & - & - & - & - & - & - & - & 5 & 0,001 & - & - & - & - & - & - \\
\hline & Ephesiella abyssorum (Hansen, 1878) & SS & - & - & - & - & - & - & - & - & - & - & 55 & 0,009 & - & - & - & - & 4 & 0,002 \\
\hline & Pista cristata (O.F. Müller, 1776) & $\mathrm{S}$ & - & - & - & - & - & - & - & - & - & - & 12 & 0,263 & - & - & - & - & - & - \\
\hline & Schistomeringos rudolphi (Delle Chiaje, 1828) & $\mathrm{C}$ & - & - & - & - & - & - & - & - & - & - & 12 & 0,003 & - & - & - & - & - & - \\
\hline & Sabella spallanzanii $(\mathrm{Gmelin}, 1791)$ & $\mathrm{F}$ & - & - & - & - & - & - & - & - & - & - & 5 & 0,572 & - & - & - & - & - & - \\
\hline & Syllis gracilis Grube, 1840 & $\mathrm{C}$ & - & - & - & - & - & - & - & - & - & - & 6 & 0,001 & - & - & - & - & - & - \\
\hline & Spiophanes bombyx (Claparède, 1870) & $\mathrm{S}$ & - & - & - & - & - & - & - & - & - & - & 2 & 0,001 & - & - & - & - & - & - \\
\hline 7 & Exogone naidina Orsted, 1845 & $\mathrm{C}$ & - & - & - & - & - & - & - & - & - & - & - & - & 22 & * & - & - & - & - \\
\hline & Novafabricia bilobata Martin \& Giangrande, 1991 & $\mathrm{~s}$ & - & - & - & - & 22 & 0,001 & - & - & - & - & - & - & 22 & 0,001 & - & - & - & - \\
\hline & Sigambra tentaculata (Treadwell, 1941) & $\mathrm{C}$ & - & - & - & - & - & - & - & - & - & - & 12 & 0,003 & 22 & 0,002 & - & - & - & - \\
\hline & Diopatra neapolitana Delle Chiaje, 1841 & $\mathrm{C}$ & - & - & - & - & - & - & - & - & - & - & 5 & 0,021 & 6 & 0,007 & - & - & - & - \\
\hline & Eunice harassii Aldoin \& Milne-Edwards, 1834 & $\mathrm{C}$ & - & - & - & - & - & - & - & - & - & - & 2 & 0,011 & 6 & 0,025 & - & - & - & - \\
\hline & Sabella pavonina Savigny, 1822 & $\mathrm{~F}$ & - & - & - & - & - & - & - & - & - & - & 9 & 0,092 & 6 & 0,013 & - & - & - & - \\
\hline & Spiochaetopterus typicus Sars, 1856 & M & - & - & - & - & - & - & - & - & - & - & 2 & * & 6 & 0,008 & - & - & - & - \\
\hline 8 & Ancystargis hamata (Hartman, 1969) & $\mathrm{C}$ & - & - & - & - & - & - & - & - & - & - & - & - & - & - & 11 & 0,014 & - & - \\
\hline 0 & Levinsenia gracilis (Tauber, 1879) & $\mathrm{S}$ & - & - & - & - & - & - & - & - & - & - & 12 & 0,001 & - & - & 11 & 0,004 & - & - \\
\hline
\end{tabular}




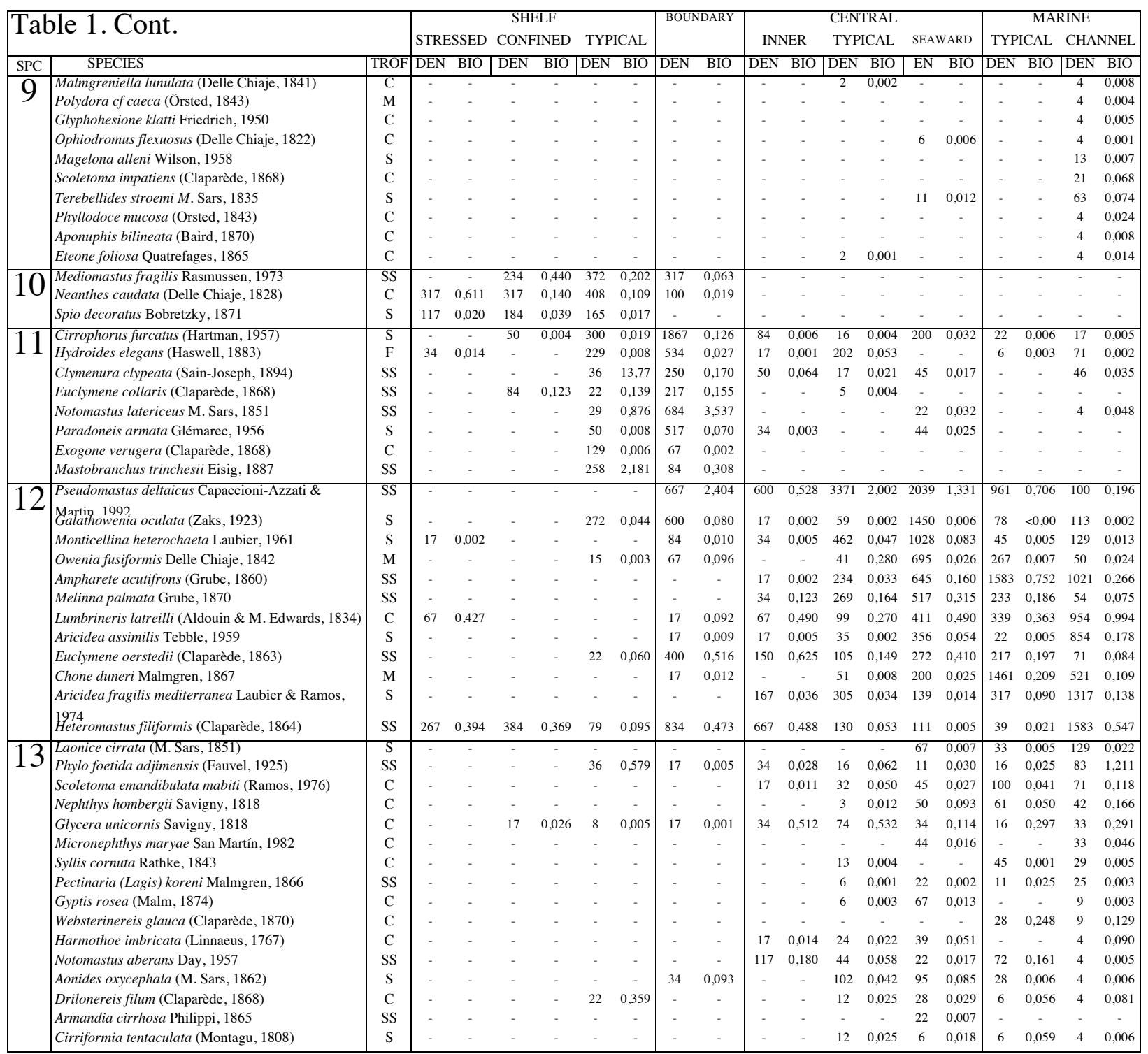


Table 2. Results of the Tukey HSD multiple comparisons post-hock test for the biological descriptors of the shelf assemblages vs. all the polychaete assemblages of Alfacs Bay. Assemblage codes as in Fig. 5.

\begin{tabular}{|c|c|c|c|c|c|c|c|c|}
\hline ABUNDANCE & $\mathrm{BOU}$ & $\mathrm{CIN}$ & CTR & CTY & $\mathrm{MCH}$ & MTY & $\mathrm{SCO}$ & SST \\
\hline $\mathrm{SCO}$ & & $\mathrm{P}<0.002$ & & $\mathrm{P}=0.03$ & & & & \\
\hline SST & $\mathrm{P}<0.005$ & & $\mathrm{P}<0.002$ & $P<0.004$ & $\mathrm{P}<0.003$ & $\mathrm{P}<0.02$ & $\mathrm{P}<0.0002$ & \\
\hline STY & & & & & & & $P<0.002$ & \\
\hline \multicolumn{9}{|c|}{ ABUNDANCE DIVERSITY } \\
\hline $\mathrm{SCO}$ & $\mathrm{P}<0.0009$ & $\mathrm{P}=0.01$ & $\mathrm{P}<0.001$ & & $\mathrm{P}<0.0006$ & $\mathrm{P}<0.03$ & & \\
\hline SST & $\mathrm{P}<0.006$ & & $P<0.007$ & & $\mathrm{P}<0.004$ & & & \\
\hline STY & & & & & & & $P<0.002$ & $P<0.02$ \\
\hline \multicolumn{9}{|c|}{ BIOMASS DIVERSITY } \\
\hline$\overline{\mathrm{SCO}}$ & & & & & $\mathrm{P}<0.02$ & & & \\
\hline SST & & & & & $\mathrm{P}<0.02$ & & & \\
\hline STY & & & & & $P=0.008$ & & & \\
\hline \multicolumn{9}{|c|}{ MEAN INDIVIDUAL BIOMASS } \\
\hline STY & & $\mathrm{P}<0.05$ & & & & & & \\
\hline
\end{tabular}




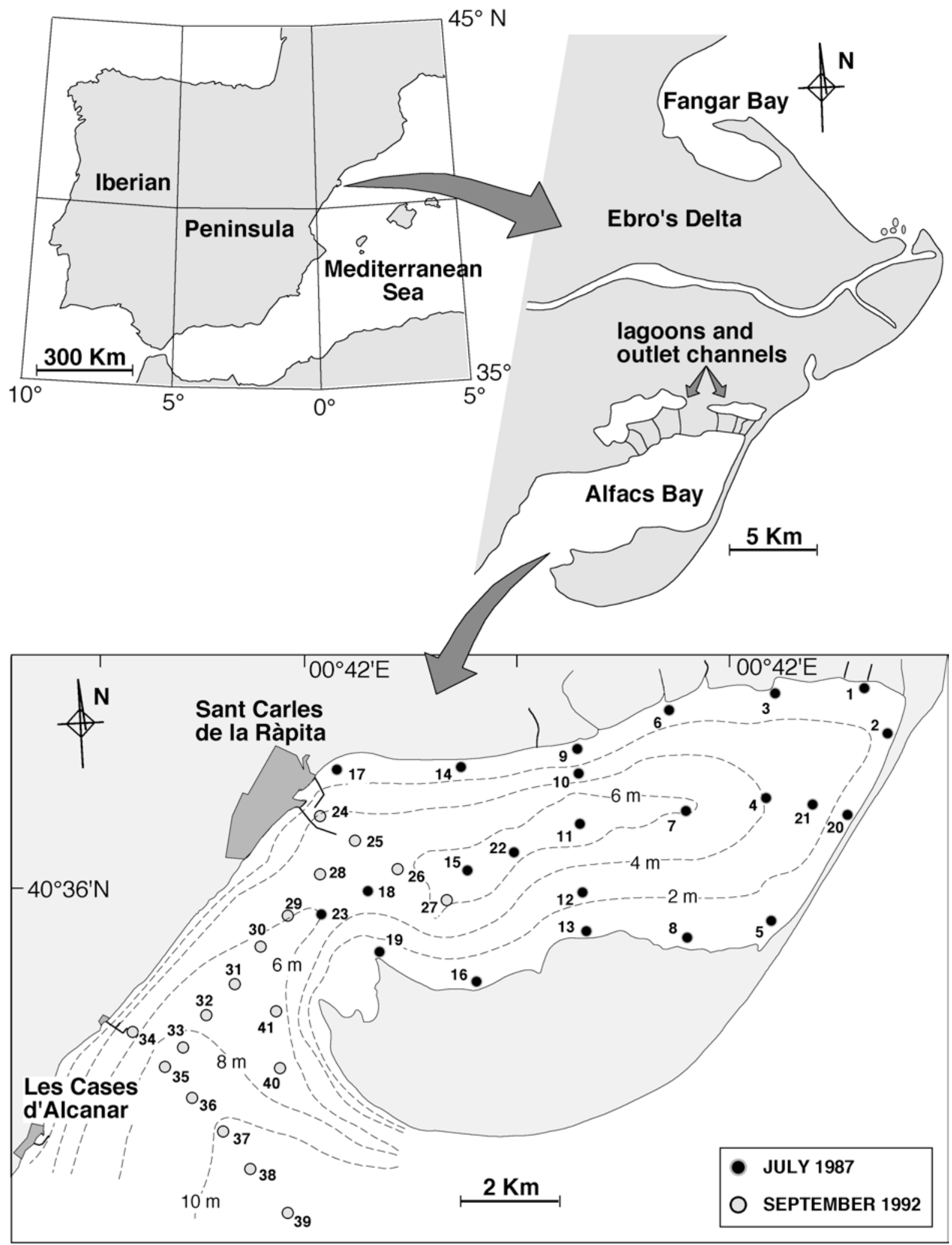

Fig. 1. Study area showing the 41 sampling stations and the bathymetry of Alfacs Bay. 

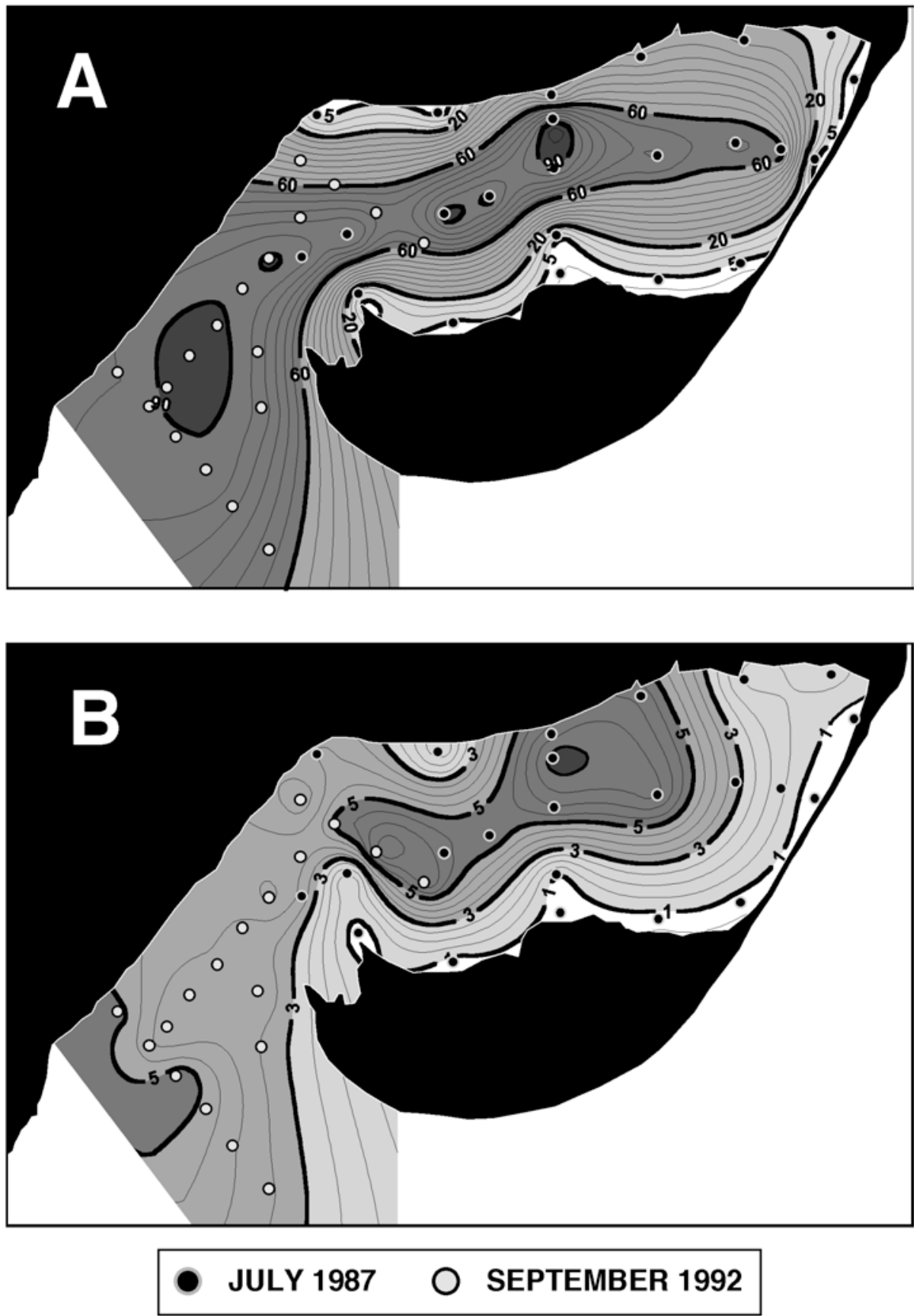

Fig. 2. Distribution pattern of sediments in Alfacs Bay. A. Silt-clay content (\% in weight). B. Organic matter content (\% in weight). 

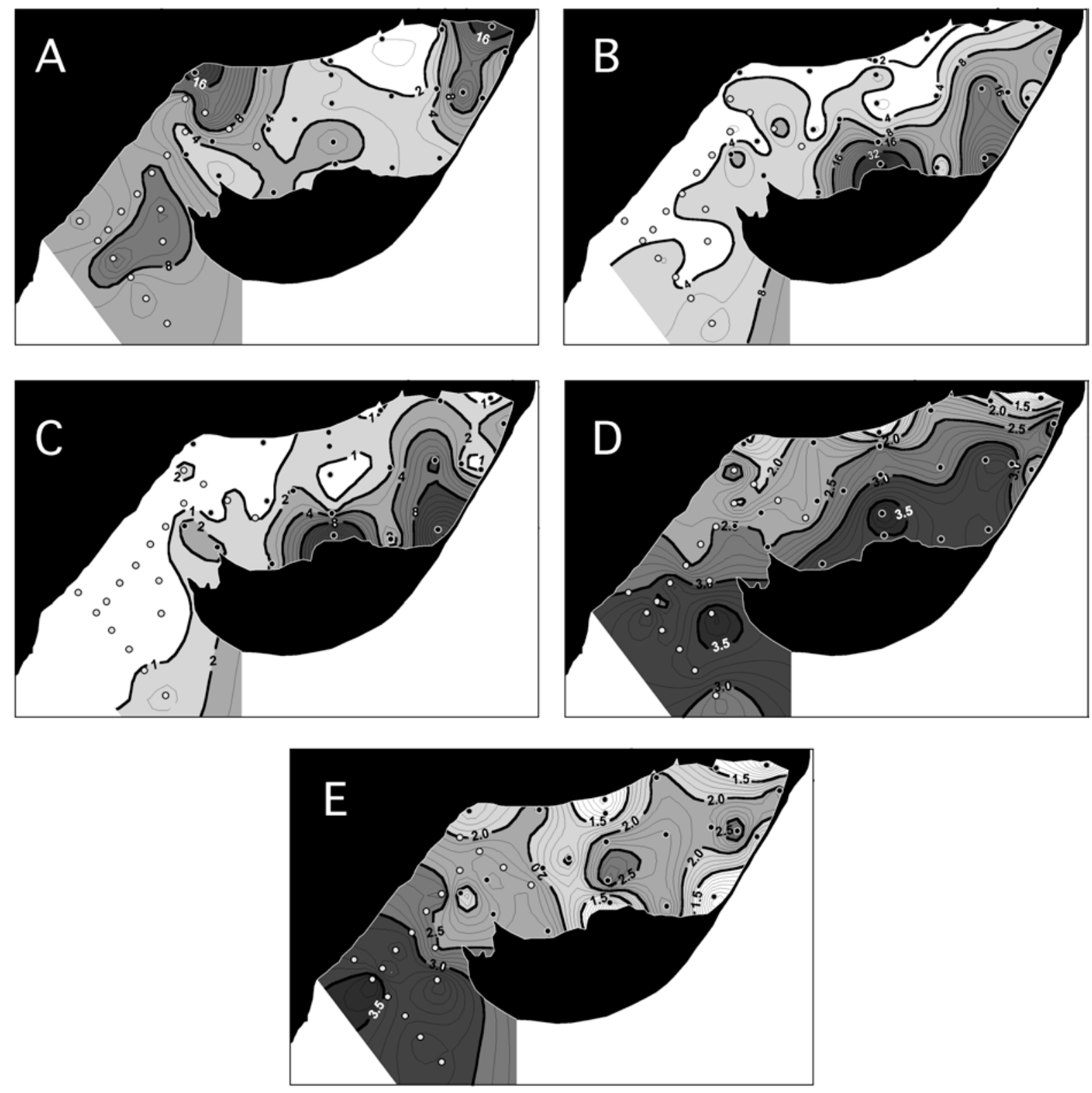

- JULY 1987 O SEPTEMBER 1992

Fig. 3. Biological descriptors of the polychaete taxocoenosis in Alfacs Bay. A. Density (ind $\cdot \mathrm{m}^{-2}$ ). B. Biomass $\left(\mathrm{DW} \mathrm{g} \cdot \mathrm{m}^{-2}\right)$. C. Mean individual biomass (DW $\left.\mathrm{g} \cdot \mathrm{ind}^{-1}\right)$. D. Shannon diversity based on density $\left(\right.$ bite $\cdot$ ind. $\left.{ }^{-1}\right)$. E. Shannon diversity based on biomass (bite $\cdot$ ind..$^{-1}$ ). 

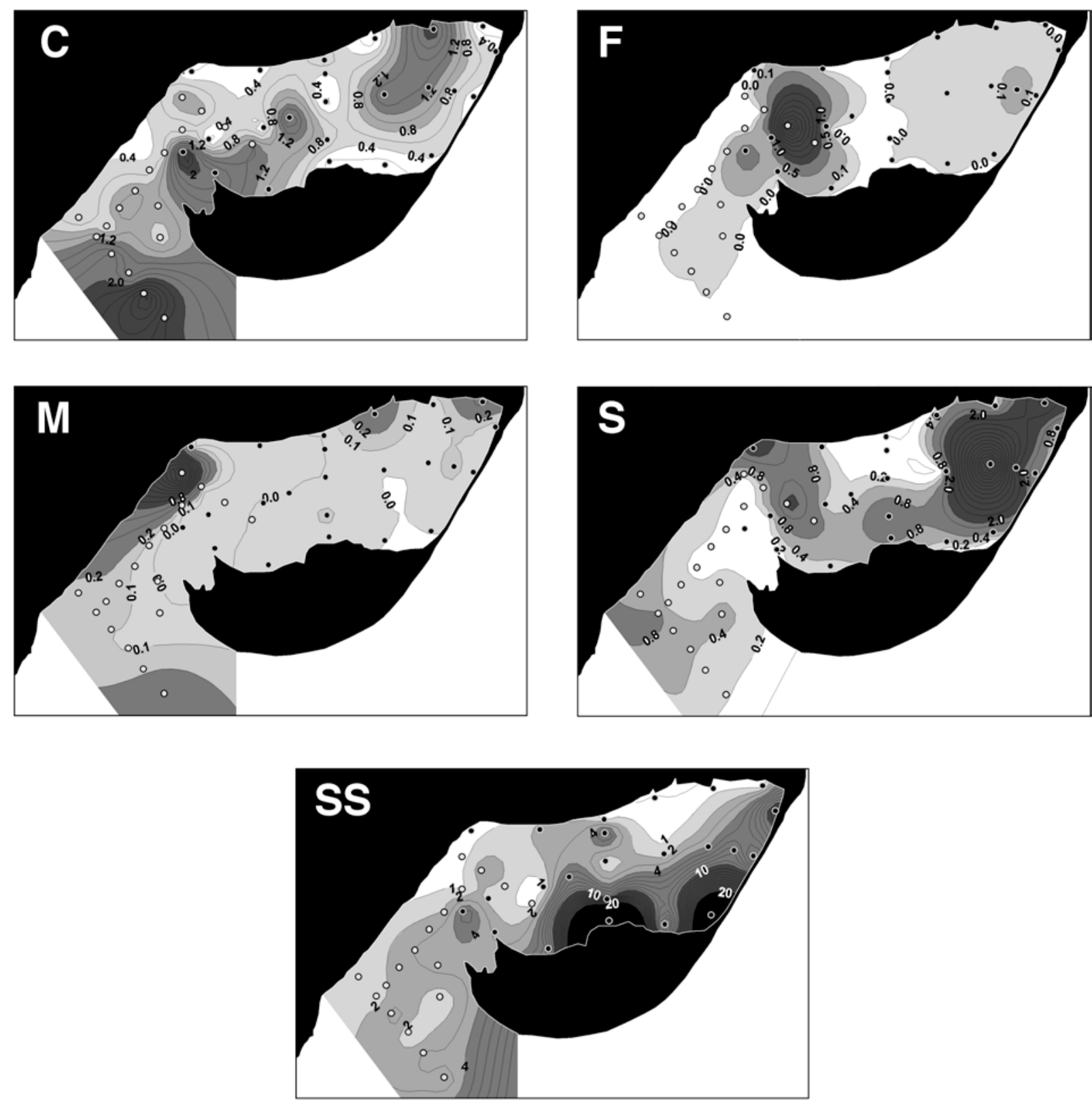

- JULY 1987 O SEPTEMBER 1992

Fig. 4. Distribution pattern of density and biomass of trophic groups in Alfacs Bay. C. Carnivorous. F. Filter feeders. M. Mixed filter and deposit feeders. S. Surface deposit feeders. SS. Subsurface deposit feeders. 

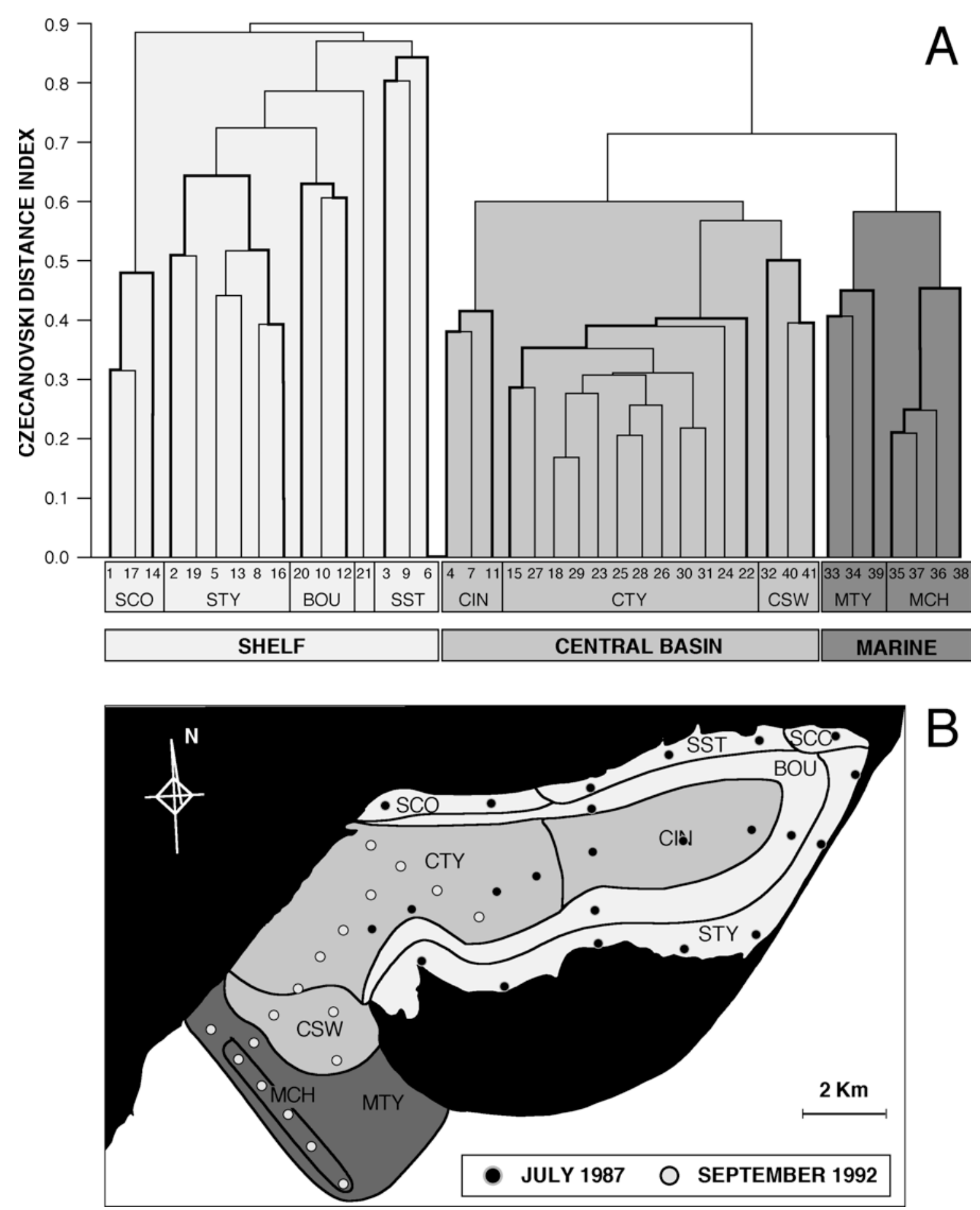

Fig. 5. Results of the cluster analysis based on polychaete density. A. Classification dendrogram based on the Czekanovski distance index. B. Scheme of sample clusters spatial distribution in Alfacs Bay. STY: typical shelf; SCO confined shelf; SST: stressed shelf; BOU: slope boundary assemblage; CIN: inner central basin; CTY: typical central basin; CSW: seaward central basin; MTY: typical marine bottom; MCH: navigation channel. 

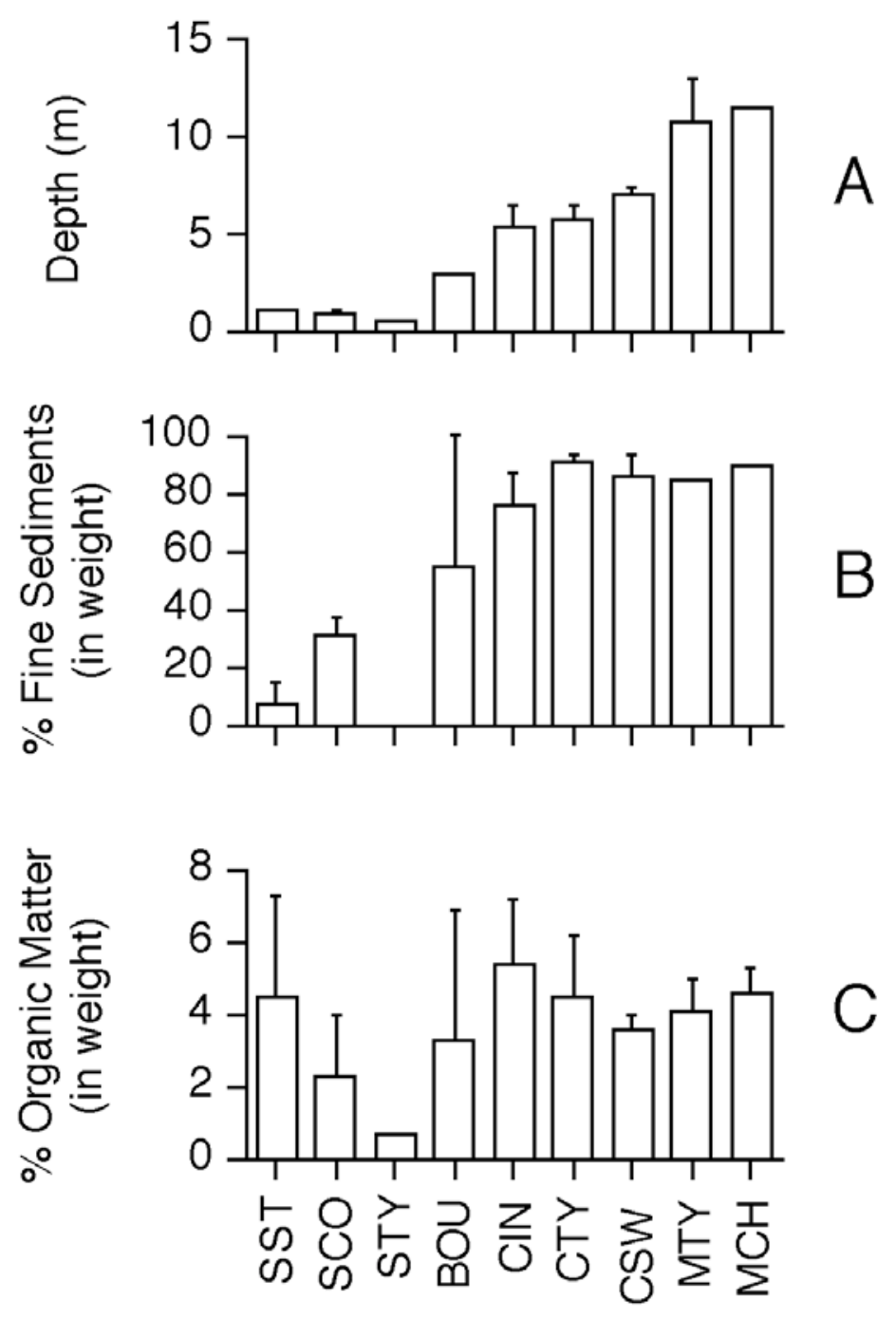

Fig. 6. Summary of the environmental characteristics for the polychaete assemblages identified in Alfacs Bay. Vertical bars are standard deviations. Assemblage codes as in Fig. 5. 

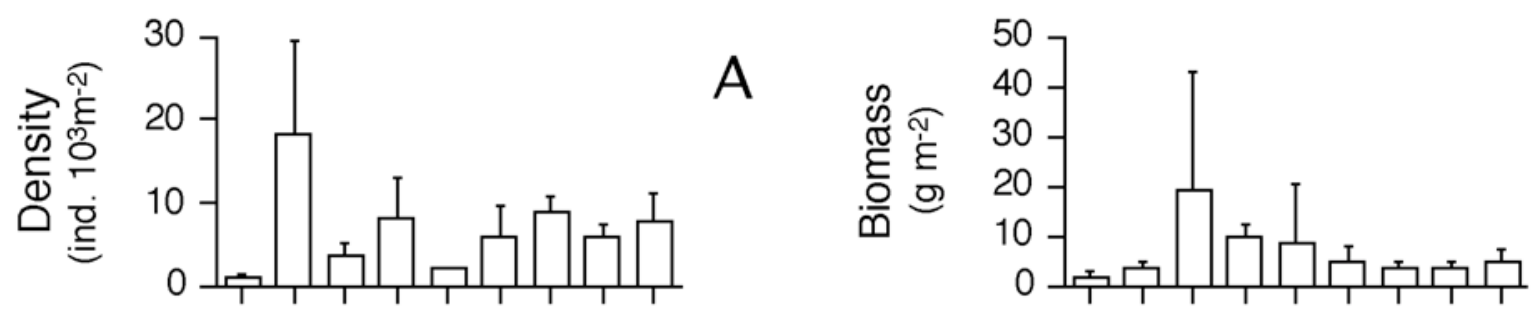

B
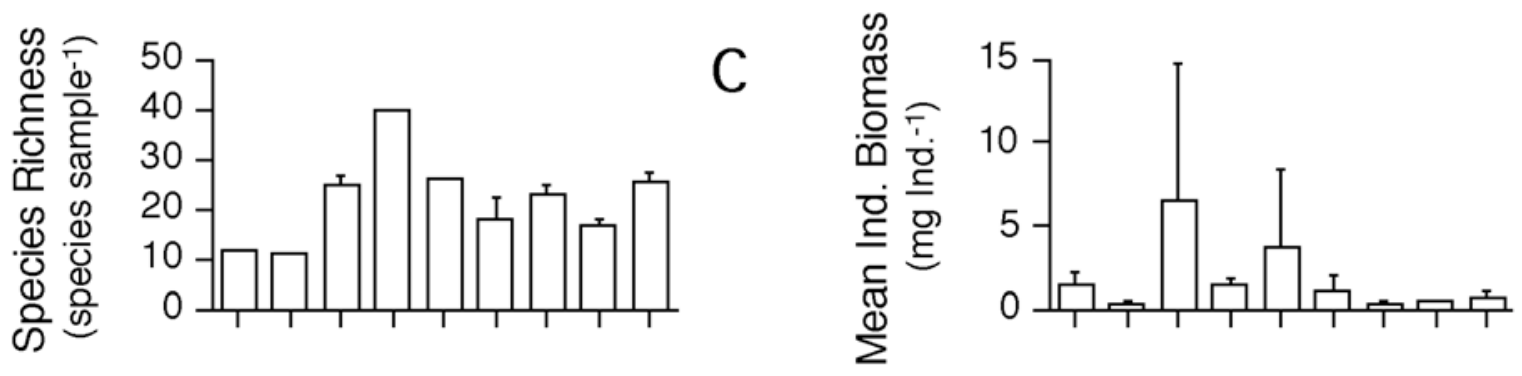

D

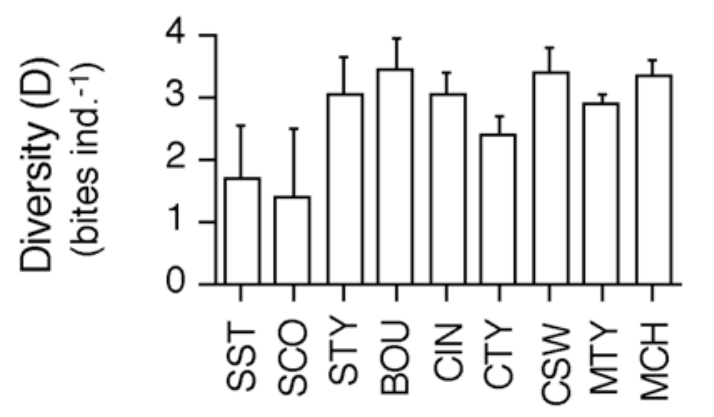

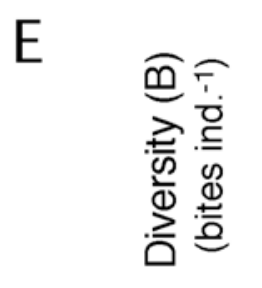

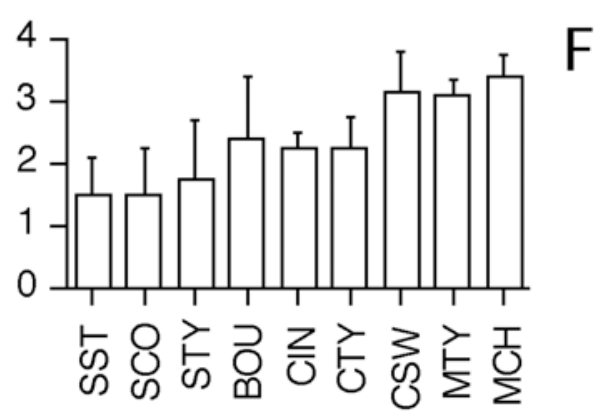

Fig. 7. Biological descriptors of the polychaete assemblages identified in Alfacs Bay. Shannon diversity was estimated on the basis of density (D) and biomass (B). Vertical bars are standard deviations. Assemblage codes as in Fig. 5. 
A

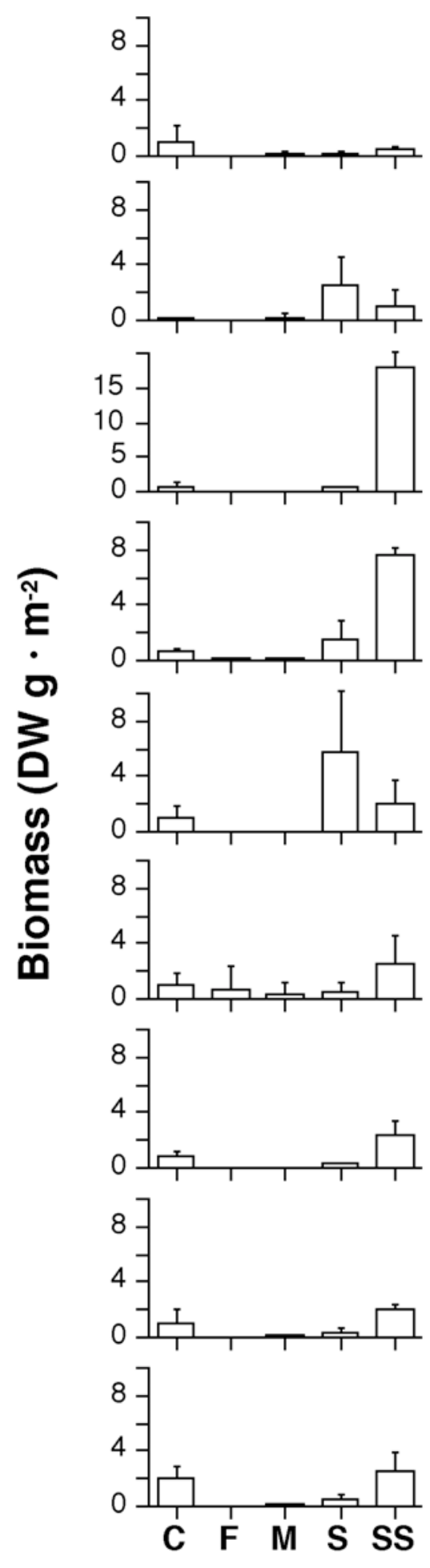

B
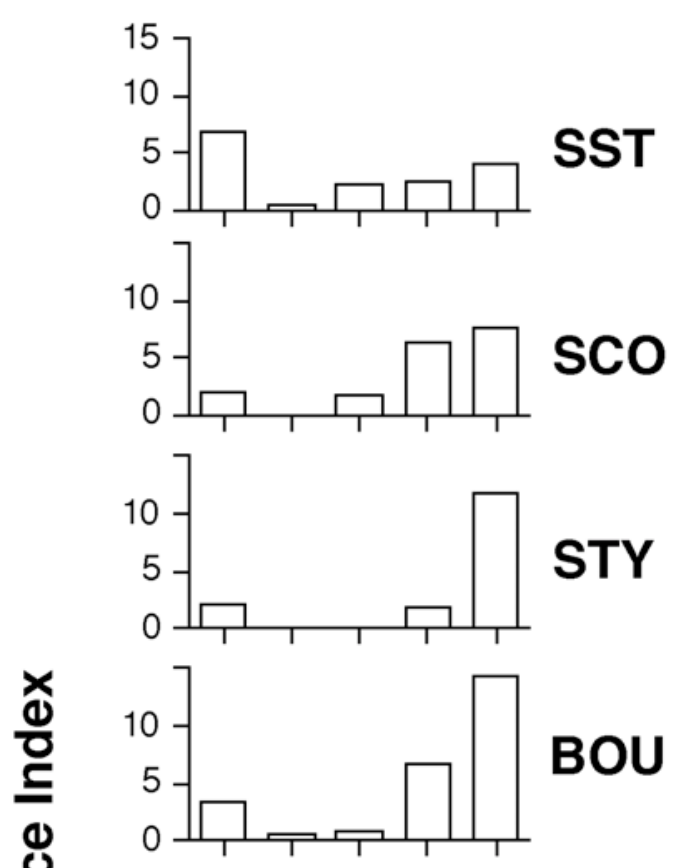

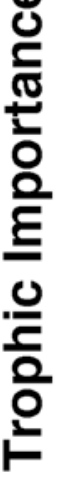
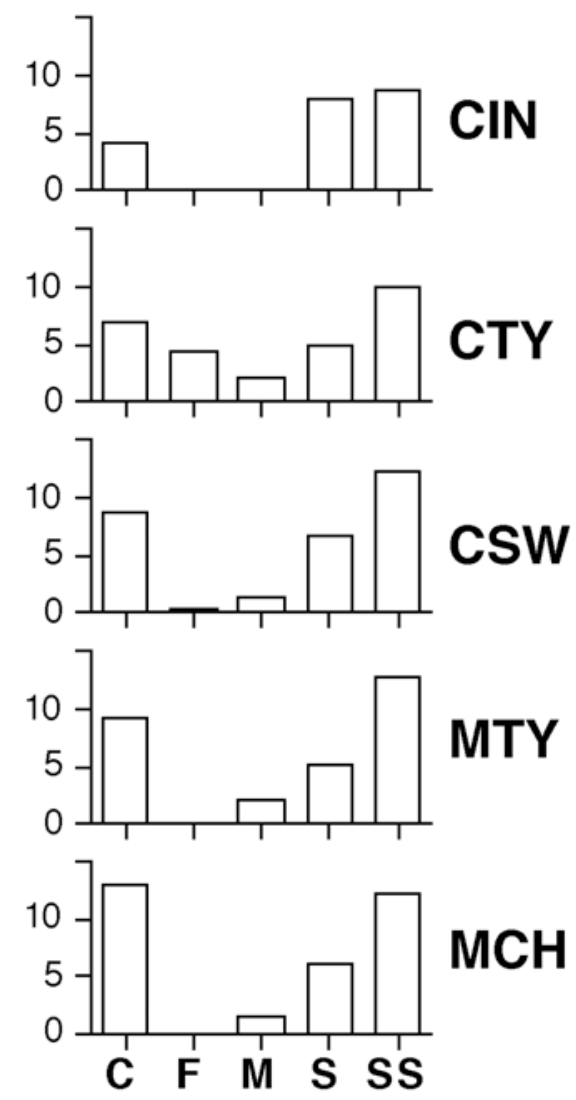

\section{$\mathrm{MCH}$}

Fig. 8. Distribution of trophic groups among the polychaete assemblages identified in Alfacs Bay. A. Average biomass. B. Trophic importance index. Vertical bars are standard deviations. Trophic group codes as in Fig. 4. Assemblage codes as in Fig. 5. 